\title{
Nanomole per Milligram of Protein
}

National Cancer Institute

\section{Source}

National Cancer Institute. Nanomole per Milligram of Protein. NCI Thesaurus. Code C67433.

A unit of concentration of amount of substance of a component measured in nanomoles of the component per milligram of protein of the mixture. 